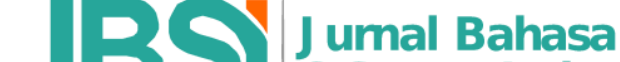 \\ JBSI
}

Volume: 1 | Nomor 1 | November 2021 | E-ISSN: 9999-999x | DOI: 10.47709/jbsi.v1i1.1232

\section{Analisis Penggunaan Bahasa Indonesia Pada Konteks Percakapan Iklan Komersil di Radio}

\author{
Author: \\ Zulkarnain Sirait ${ }^{1}$ \\ Cecep Maulana ${ }^{2}$
}

Afiliation:

STMIK ROYAL ${ }^{1,2}$

\section{Corresponding email \\ Zulkarnainsrt123@gmail.com}

This is an Creative Commons License This work is licensed under a Creative Commons Attribution-NonCommercial 4.0 International License

\begin{abstract}
Abstrak:
Penelitian ini membahas tentang masih banyaknya kesalahan dalam penggunaan bahasa Indonesia. Pemakaian bahasa dan fungsi bahasa dapat ditemukan dalam berbagai macam kegiatan, salah satunya adalah kegiatan perdagangan khususnya penawaran barang dalam bentuk iklan. Bahasa dalam iklan sangat berpengaruh bagi masyarakat yang berperan sebagai alat komunikasi antara produsen terhadap konsumen. Penelitian ini membahas konteks percakapan yang terjadi pada iklan di Radio. Tujuan penelitian ini adalah untuk mengetahui hubungan antara konteks dan teks, dan penggunaan bahasa Indonesia pada percakapan iklan.

Sumber data dalam penelitian ini adalah rekaman iklan radio komersil dan layanan masyarakat yang direkam melalui siaran Prambors radio dan IRadio Medan. Penelitian ini adalah penelitian yang berfokus pada hubungan antara konteks dan teks, dan analisis penggunaan bahasa Indonesia sebagai upaya untuk mengukur sejauh mana bahasa Indonesia digunakan dalam setiap keperluan. Data dikumpulkan dengan menggunakan teknik rekam, simak dan teknik catat. Lalu dianalisis menggunakan metode kualitatif interaktif, merupakan studi yang mendalam menggunakan teknik pengumpulan data langsung.

Hasil penelitian ini menunjukkan bahwa antara konteks dan teks memiliki hubungan erat yang tak dapat dipisahkan. Kemudian masih banyak iklan yang tidak menggunakan bahasa Indonesia yang baik dan benar sesuai dengan Ejaan bahasa Indonesia (EBI). Pada iklan komersil yang berjudul "Teh Sariwangi" memperlihatkan adanya potongan peristiwa percakapan pada sebuah warung antara si penjual dan si pembeli. Dengan produk yang ditawarkan "Teh Sariwangi" dalam bentuk sachet "Sariwangi, hangatnya kebersamaan". Penyampaian pesan pendek pada kalimat kurang maksimal karena penyiar tidak menjelaskan manfaat atau kelebihan-kelebihan lain jika dibandingkan teh produk lainnya.
\end{abstract}

Kata kunci: Analisis, Bahasa Indonesia, Konteks, Percakapan, Iklan Komersil.

\section{Pendahuluan}

Pemakaian bahasa dan fungsi bahasa dapat ditemukan dalam berbagai macam kegiatan, salah satunya adalah kegiatan perdagangan khususnya penawaran barang dalam bentuk iklan. Dalam iklan kalimatkalimat yang dilontarkan untuk konsumen biasanya disusun menarik dan rapi agar para konsumen tertarik akan benda yang dipasarkan lewat iklan. Bahasa dalam iklan sangat berpengaruh bagi masyarakat yang berperan sebagai alat komunikasi antara produsen terhadap konsumen.

Proses komunikasi dapat terjadi antara individu dengan individu, individu dengan kelompok, kelompok dengan kelompok lainnya. Pemakaian bahasa berkaitan dengan pemahaman agar tercipta dan tercapai 


\section{JBST}

Volume: 1 | Nomor 1 | November 2021 | E-ISSN: 9999-999x | DOI: 10.47709/jbsi.v1i1.1232

pengertian yang sama antara penulis dengan pembaca. Begitu pula bahasa yang terdapat pada iklan, posisi bahasa sangatlah mempunyai peran yang sangat penting dalam susunan kalimat iklan, Seorang penulis iklan harus dapat menggunakan bahasa yang menarik agar iklan tersebut menimbulkan kesan, memancing reaksi masyarakat dan membangkitkan perhatian konsumen, sehingga mereka dapat memahami makna dan bentuk yang terkandung dalam iklan tersebut. Ada dua macam media massa yang digunakan untuk menyampaikan informasi (iklan) yaitu media elektronik dan media non-elektronik.

Bahasa juga merupakan salah satu faktor penting penentu keberhasilan iklan. Bahasa yang digunakan dalam iklan disusun dengan kata-kata yang mengandung daya persuasif yang komunikatif. Bahasa persuasif yaitu bahasa yang bersifat mempengaruhi konsumen agar membeli produk yang ditawarkan dalam berbagai bentuk dan disampaikan lewat berbagai media. Oleh karena itu, bahasa sebagai sarana komunikasi dalam sebuah iklan menjadi sangat menarik untuk dikaji lebih lanjut. Dikatakan menarik karena dari sisi bahasa dan desain iklan sangatlah beragam.

Iklan bisa dikategorisasikan dan bahkan dinilai berbeda-beda oleh setiap konsumen. Iklan rokok Sampoerna Hijau, sebagai salah satu contoh, dinilai oleh sebagian orang merupakan iklan yang lucu. Namun, bagi sebagian orang yang lain mengatakan iklan tersebut merupakan iklan menarik. Iklan tersebut dianggap lucu atau menarik karena menceritakan Geng Hijau yang dikemas secara menyenangkan dan humoris. Sampai saat ini, ceritanya sudah dibuat dalam beberapa versi dengan tema yang hampir sama yakni tentang kebersamaan. Saat pertama kali muncul tahun 2000, slogan yang diangkat adalah "Asyiknya Rame-rame". Iklan ini ternyata sangat terkenal di masyarakat. Slogan "ijo-ijo" pun menjadi ungkapan yang mudah diingat oleh konsumen. Dikatakan "ijo-ijo" karena semua atribut rokok dan bungkus identik dengan warna hijau dan hal ini menjadi ikon rokok tersebut.

Dalam dunia usaha pada khususnya, produsen tidak dapat secara langsung bertemu dan memasarkan produknya kepada konsumen. Dalam situasi seperti ini, iklan merupakan salah satu solusi karena di manapun dan kapanpun, mereka dapat berkomunikasi dengan menggunakan media tersebut.

Nampaknya permasalahan yang dijumpai dalam proses komunikasi adalah permasalahan bahasa. Pemahaman konsumen yang berbeda terhadap dialog yang terdapat pada iklan tentunya dapat membuat makna pesan iklan menjadi tidak jelas.

Sebagai contoh, produsen menggunakan istilah up to yang dalam bahasa Indonesia diterjemahkan 'hingga'. Bila diperhatikan, di toko pakaian banyak tulisan "diskon dari $10 \%$ up to $50 \%$ " dan bersifat promosi. Ini artinya bahwa dari setiap seratus jumlah barang yang ditawarkan kepada konsumen, ada sepuluh barang yang diberikan diskon hingga pada angka tertentu. Dengan demikian, tidak semua barang mendapatkan diskon. Kemudian, bila kita menemui iklan restoran "Paket OK Rp 36.500++/pax" maka kita mungkin beranggapan bahwa paket ini sangat murah. Tapi pada kenyataannya konsumen bisa menghabiskan lebih dari seratus ribu rupiah untuk makan berdua; tentunya setelah ditambah dengan harga minuman dan biaya pajak dan pelayanan (tax and service). Kata kunci dari iklan tersebut adalah pada tulisan "/pax". Hal ini merupakan teknik promosi yang menjebak namun banyak konsumen yang belum memahaminya.

Dari contoh diatas bahasa pada iklan mempunyai daya tarik tersendiri di mana konsumen menjadi tertarik untuk mengingat bahkan secara rasional dan emosional terdorong untuk membeli produk yang diiklankan. Bahasa iklan memang sudah dirancang sedemikian rupa dan ada maksud tertentu dibalik iklan yang tidak dinyatakan secara lugas. Dalam suatu percakapan seperti halnya pada sebuah iklan, setiap bentuk percakapan iklan menggunakan bahasa sebagai alat utama untuk melakukan penggambaran tentang sebuah realitas. Dalam hal ini, bahasa digunakan untuk dua kepentingan sekaligus. Pertama, bahasa digunakan 


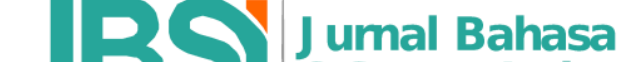 \\ JBS assastrantonosia}

Volume: 1 | Nomor 1 | November 2021 | E-ISSN: 9999-999x | DOI: 10.47709/jbsi.v1i1.1232

sebagai salah satu sarana untuk mendeskripsikan realitas barang (produk) yang akan ditawarkan/diiklankan. Kedua, setelah deskripsi barang ditampilkan, bahasa juga digunakan untuk membentuk citra pada barang tersebut.

Sebagai salah satu bentuk komunikasi, iklan menggunakan bahasa sebagai salah satu media penyampaian pesan. Dengan kata lain, bahasa merupakan bagian penting dari komunikasi, termasuk komunikasi periklanan. Komunikasi dalam iklan pada dasarnya juga sebagai salah satu upaya menyampaikan ide, emosi, dan keinginan dengan format dan variasi tertentu. Oleh karena itu, pemanfaatan bahasa dalam iklan juga berkaitan dengan fungsi hakiki bahasa itu sendiri.

Aspek verbal merupakan kondisi penting dalam suatu program periklanan. Kenyataannya untuk beberapa produk, ketiadaan komunikasi lisan atau kata-kata sebagai perwujudan aspek verbal dapat berakibat fatal karena komunikasi lisan atau kata-kata mempunyai kredibilitas, komprehensif, dan berpengaruh kepada khalayak. Hal itu diperkuat dengan kenyataan bahwa bahasa (verbal) dapat digunakan sebagai alat bantu memori. Bahasa verbal membuat memori lebih efisien bila kita akan menyandi suatu pesan. Para peneliti menunjukan bahwa ternyata kita lebih mudah mengenali kembali warna, isyarat, suara yang mungkin sulit disifatkan, bila sudah dinamai dengan menggunakan bahasa verbal.

Demikian halnya dengan iklan-iklan yang ada di kota Medan berusaha untuk mempertahankan pangsa pasarnya sehingga produk yang dipasarkannya dapat terus dipertahankan bahkan ditingkatkan, hal ini sangat penting mengingat salah satu sumber pendapatan kota Medan adalah iklan dari penjualan berbagai produk yang ada. Adapun upaya yang dilakukan oleh produsen yang ada di kota medan untuk meningkatkan penjualan produk-produk yang ada yaitu dengan memasang iklan melalui media cetak dan media elektronik.

\section{Studi Literatur}

Bahasa adalah sebuah sistem, artinya bahasa dibentuk oleh sejumlah komponen yang berpola secara tetap dan dapat diindahkan. Sistem bahasa berupa lambang- lambang bunyi, setiap lambang bahasa melambangkan sesuatu yang disebut makna atau konsep. Karena setiap lambang bunyi itu memiliki atau menyatakan suatu konsep atau makna, maka dapat disimpulkan bahwa setiap suatu ujaran bahasa memiliki makna, Abdul Chaer dan Leonie Agustina (2004:11).

Menurut Gorys Keraf (dalam hakim, 2011: baris 15), Bahasa adalah alat komunikasi antara anggota masyarakat berupa simbol bunyi yang dihasilkan oleh alat ucap manusia. Bahasa adalah alat komunikasi antar anggota masyarakat Indonesia. Bahasa juga menunjukkan perbedaan antara satu penutur dengan penutur lainnya, tetapi masing-masing tetap mengikat kelompok penuturnya dalam satu kesatuan sehingga mampu menyesuaikan dengan adat-istiadat dan kebiasaan masyarakat. Selain itu, fungsi bahasa juga melambangkan pikiran atau gagasan tertentu, dan juga melambangkan perasaan, kemauan bahkan dapat melambangkan tingkah laku seseorang.

Berbicara tentang wacana selalu berkaitan dengan konteks, seperti dikatakan oleh Sudaryat (2009:141) bahwa konteks merupakan ciri-ciri alam di luar bahasa yang menumbuhkan makna pada ujaran atau wacana (lingkungan non linguistik dari wacana). Menurut Kleden dalam Sudaryat (2009:141) menjelaskan bahwa konteks adalah ruang dan waktu yang spesifik yang dihadapi seseorang atau kelompok orang. Konteks menjadi penting kalau dihayati secara tektual sehingga menjadi terbuka untuk pembaca dan penafsiran oleh siapa saja. 


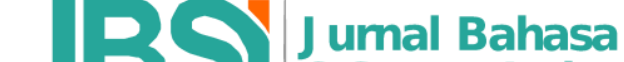 \\ JBS assastrantonosia}

Volume: 1 | Nomor 1 | November 2021 | E-ISSN: 9999-999x | DOI: 10.47709/jbsi.v1i1.1232

\section{Metode Penelitian}

Metode yang digunakan dalam penelitian ini adalah metode deskriptif analisis. Metode ini memberikan gambaran secara rinci tentang adjektiva. Sevilla mengatakan (dalam Lubis, 2014:49) metode deskriptif analisis adalah metode yang menganalisis data berdasarkan bahan yang diperoleh tanpa menambahi atau mengurangi kemudian menganalisisnya. Prosedur pemecahan masalah dengan cara menggambarkan atau mengungkapkan subjek atau objek yang diteliti secara apa adanya, artinya sesuai dengan fakta pada saat penelitian dilakukan.

Sudaryanto mengatakan (dalam Mustofa, 2010: 22) "Istilah deskriptif itu menyarankan bahwa penelitian yang dilakukan semata-mata hanya berdasarkan pada fakta yang ada atau fenomena yang memang secara empiris hidup pada penutur-penuturnya, sehingga yang dihasilkan atau yang dicatat berupa perian bahasa yang biasa dikatakan sifatnya seperti potret: paparan seperti adanya".

Berdasarkan pendapat tersebut dapat disimpulkan bahwa metode deskriptif adalah prosedur pemecahan masalah yang diselidiki dengan menggambarkan keadaan objek penelitian berdasarkan pada fakta-fakta yang ada. Metode deskriptif ini digunakan karena penelitian ini bertujuan untuk mendeskripsikan bentuk percakapan iklan komersil di radio.

\section{Hasil}

Iklan komersil adalah jenis iklan yang menawarkan barang dan jasa. Sebagian besar iklan yang kita temui di berbagai tempat merupakan iklan komersil. Salah satu iklan yang dianalisis berikut ini adalah iklan Teh Sariwangi.

Berikut ini akan dipaparkan iklan Teh Sariwangi yang disiarkan melalui radio sebagai berikut:

A : Ini kembalinya masih kurang. Nggak ada lima ratusannya. Pake permen aja, ya, Bu, ya? Nggak apaapa ya, Bu, ya?

B : Nggak bisa, adik juga nggak mau kan kalo saya belanja bayarnya pake permen?

A : Ya, udah ini shampo sachet aja Bu. Shamponya harganya pas lima ratus.

$B$ : Nggak. Kan saya udah bilang, kalau bayarnya pake uang, kembaliannya juga pake uang dong!

$A$ : Ah, lima ratus aja, Bu...

$B$ : Eh, Adik jangan anggap enteng uang lima ratus. Uang lima ratus itu bisa buat macem-macem lho!. Tau nggak, dengan uang lima ratus aja, saya bisa ngumpulin sampai 15 orang.

A : Hah? Caranya gimana, Bu?

$B$ : Sekarang kan ada Sariwangi sachet isi 5 cuma lima ratus rupiah bisa buat 15 orang.

A : Kalo gitu, lima ratus nya saya kembaliin pake Sariwangi sachet isi 5 ya Bu, ya kan? Pulang dari sini, Ibu bisa ajak serta keluarga, teman, saudara, tetangga, terus jangan lupa Bu, ajak-ajak saya...

Narator: Sariwangi, hangatnya kebersamaan.

Iklan Teh Sariwangi memperlihatkan sebuah potongan peristiwa percakapan di sebuah warung yang menjual kebutuhan sehari-hari, seperti beras, gula, teh, shampo, dan permen. Dialog dalam iklan tersebut melibatkan dua orang, yakni seorang pembeli (ibu-ibu) dan penjual/penjaga (remaja perempuan) di sebuah warung kelontong milik keluarga remaja perempuan tersebut. Seperti biasa yang sering terjadi di masyarakat kita, pada saat transaksi jual-beli selesai, uang kembalian (jika berupa uang receh) tidak diberikan dalam bentuk uang, tetapi dalam bentuk yang lain, seperti permen atau shampo sachet. Sebagai pembeli, si ibu, dipaksa oleh penjual, untuk menerima kembalian yang berupa barang pengganti uang, dengan berbagai alasan bahwa uang receh sebesar lima ratus rupiah tidak tersedia di warungnya. Mungkin, 


\section{JBST}

Volume: 1 | Nomor 1 | November 2021 | E-ISSN: 9999-999x | DOI: 10.47709/jbsi.v1i1.1232

penjual mempunyai alasan tersendiri mengapa dia melakukan hal itu. Barangkali, kembalian yang nilai nominalnya kecil (menurut penjual) lebih baik tidak dikembalikan dalam bentuk uang, tetapi diganti barang alih-alih untuk menambah hasil penjualan di warungnya.

Dalam dialog iklan teh Sariwangi penjual/penjaga warung, dengan tidak merasa terbebani, mengatakan kepada pembeli bahwa uang kembalian masih kurang lima ratus rupiah. Bahkan, penjaga warung memaksa pembeli untuk menerima beberapa buah permen senilai lima ratus rupiah. Akan tetapi, pembeli bersikeras tidak mau menerima kembalian yang berupa permen dengan mengatakan"Nggak bisa. Adik juga nggak mau kan kalo saya belanja bayarnya pake permen?" Si penjaga warung ternyata tidak kekurangan akal ketika permen ditolak oleh pembeli. Sebagai gantinya, penjaga warung menyerahkan shampo yang berbentuk sachet yang nilai nominalnya juga lima ratus rupiah. Akan tetapi, si pembeli tetap menolak, bahkan mengulang pernyataan sebelumnya, yakni "Nggak. Kan saya udah bilang kalo bayarnya pake uang, kembaliannya juga pake uang dong!" Dengan tidak merasa bersalah, penjaga warung/penjual menganggap bahwa kembalian lima ratus rupiah itu tidak ada artinya, seperti dalam kalimat" Ah, lima ratus aja, Bu”.

Tak diduga oleh penjaga warung, si ibu pembeli marah-marah sambil mengatakan"Eh, Adik jangan anggap enteng uang lima ratus. Uang lima ratus itu bisa buat macem- macem lho! Tau nggak, dengan uang lima ratus aja, saya bisa ngumpulin sampai 15 orang." Saat itu si penjaga warung terheran-heran dan tidak percaya bagaimana mungkin uang sebesar lima ratus rupiah dapat digunakan untuk mengumpulkan orang sebanyak 15 dengan mengatakan"Hah, caranya gimana, Bu?" Dengan suara lantang dan menggebu-gebu pembeli menjelaskan bahwa sekarang ada teh Sariwangi sachet isi lima cuma lima ratus rupiah dan bisa dimanfaatkan untuk 15 orang. Setelah mendapat penjelasan dari pembeli, penjaga warung menyerahkan kembalian berupa teh Sariwangi sachet isi 5 sambil ia berpesan kepada pembeli (agak bercanda), "Kalo gitu, lima ratusnya saya kembaliin pake Sariwangi sachet isi 5 ya, Bu, ya kan? Pulang dari sini, Ibu bisa ajak serta keluarga, teman, saudara, tetangga, terus jangan lupa, Bu, ajak-ajak saya”. Dalam dialog tersebut tidak tampak pembeli menyetujui atau menolak. Akhir dialog iklan teh Sariwangi ditutup oleh suara penyiar laki-laki dengan mengatakan secara pelan-pelan "Sariwangi, hangatnya kebersamaan."

Jika diperhatikan, dialog atau percakapan antara penjaga warung dan pembeli itu berada pada tingkatan yang kurang akrab. Hal ini terbukti dengan nada-nada tinggi yang diucapkan oleh si pembeli. Jika antara pembeli dan penjual sudah terjalin keakraban sebelumnya, mungkin si ibu sebagai pembeli akan diam atau menurut saja (misalnya karena sudah kenal baik) ketika si penjual/penjaga warung memberikan kembalian bukan dalam bentuk uang, tetapi dalam bentuk permen. Percakapan antara si pembeli dan penjual/penjaga warung baru terasa akrab pada akhir dialog. Hal ini terbukti dengan kemauan si pembeli untuk menjelaskan teh Sariwangi kemasan sachet, "Sekarang kan ada Sariwangi sachet isi 5 cuma lima ratus aja, saya bisa ngumpulan sampai 15 orang”.. Di sinilah daya kreatif pembuat iklan teh Sariwangi dapat dirasakan oleh pendengar. Hal ini terbukti bahwa penjelasan tentang teh Sariwangi justru bukan dari si penjual. Selain itu, iklan ini menganggap bahwa konsumen telah akrab dengan teh Sariwangi.

Selain itu, hubungan kedua pemeran iklan tersebut dirasakan oleh pendengar radio dari beberapa aspek, seperti (1) bahasa yang digunakan, (2) topik, (3) setting atau latar dan (4) produk yang ditawarkan.

Percakapan si pembeli dan penjual dapat dimengerti dengan baik oleh orang lain karena bahasa yang digunakan dalam dialog iklan tersebut juga mudah dipahami. Dalam situasi marah atau kurang enak suasana hati, pemakaian kata-kata tidak baku biasa dilakukan dalam percakapan. Selain itu, kemungkinan lain adalah si ibu sebagai pembeli merasa mempunyai status sosial lebih tinggi jika dibandingkan dengan status sosial si penjual, sehingga kata-kata yang dipilih pun tidak baku. Meskipun demikian, kata sapaan yang 


\section{JBS J Jumal Bahase \\ JBS assastrantonosia}

Volume: 1 | Nomor 1 | November 2021 | E-ISSN: 9999-999x | DOI: 10.47709/jbsi.v1i1.1232

digunakan, baik oleh si pembeli maupun si penjual terasa sopan, yakni adik (sapaan untuk si penjual) dan $i b u$ (sapaan untuk si pembeli) bukan kata kamu yang dipilih untuk menyapa si penjual meskipun penjaga warung itu masih remaja.

Aspek yang kedua dalam dialog iklan teh Sariwangi adalah topik. Topik iklan ini diawali oleh si penjual ketika menyerahkan kembalian kepada pembeli dengan mengatakan "Nggak ada lima ratusan. Pake permen aja, ya, Bu, ya? Nggak apa-apa ya, Bu, ya? Topik dialog berikutnya masih tentang kembalian berupa shampo sachet yang nilainya sama dengan uang kembalian si pembeli. Namun, kembalian tersebut tetap ditolak oleh pembeli. Akhirnya, topik tentang teh Sariwangi sachet terangkat ketika pembeli menyatakan kepada penjual/penjaga warung bahwa penjual tidak boleh menganggap enteng uang kembalian lima ratus karena manfaatnya besar sekali, yakni mampu mengumpulkan lima belas orang.

Aspek ketiga adalah latar terjadinya peristiwa dialog tersebut, yakni di sebuah warung yang menyediakan barang-barang keperluan sehari-hari. Aspek yang keempat adalah produk yang ditawarkan, yakni teh Sariwangi dalam bentuk sachet. Di dalam aspek ini tidak dijelaskan oleh pemeran dialog iklan kelebihankelebihan teh Sariwangi sachet jika dibandingkan dengan produk teh yang lain, seperti rasanya, aromanya, atau manfaatnya untuk kesehatan. Hanya, di akhir iklan ini ditegaskan oleh narator tentang kehangatan situasi jika bersama-sama meminum teh sariwangi, tetapi bukan keistimewaan produk teh Sariwangi.

Padahal, pada awal-awal dialog iklan telah tergambar bahwa iklan yang disiarkan melalui radio itu dibuat semudah dan sealami mungkin agar pesan pengiklan cepat sampai kepada pendengar dengan tepat pula. Sayangnya, materi utama teh Sariwangi justru tidak dijelaskan secara detail. Hal ini mungkin disebabkan oleh anggapan si pengiklan bahwa pendengar sudah terlalu akrab terhadap produknya. Alasan lain yang dapat dikemukakan mungkin, jika dialog terlalu panjang malah membingungkan pendengar, atau alasan lain, yakni biaya untuk beriklan semakin panjang waktu berarti semakin mahal.

Jadi, pesan produk secara verbal mengenai teh Sariwangi dalam bentuk sachet secara khusus hanya melalui lisan pengisi dialog (pemeran iklan) dan penyiar (pengisi suara) hanya mengulang atau mengingatkan kembali produk yang ditawarkan, "Sariwangi, hangatnya kebersamaan." Penyampaian pesan pendek oleh penyiar terasa kurang maksimal karena penyiar tidak menjelaskan manfaat atau kelebihan-kelebihan lain jika dibandingkan dengan teh produk lain.

\section{Pembahasan}

Dalam iklan komersil yang berjudul "Teh Sariwangi" terdapat beberapa pemilihan kata yang tidak tepat, seperti pada kata "Nggak, pake, aja, udah, enteng, macem-macem, ngumpulin, gimana, kalo, cuma, tau, gitu, kembaliin, dan terus". Pemilihan kalimat maupun kata tidak menggunakan ragam bahasa baku, bahasa yang digunakan dalam iklan bahasa yang sangat ringan dan mudah dipahami oleh para pendengar radio baik muda maupun orang tua.

Dalam beberapa kalimat pada iklan tersebut terdapat kata yang tidak efektif, contoh pada kalimat "Nggak ada lima ratusannya". Dalam kalimat tersebut terdapat kata "Nggak", kata tersebut adalah kata yang tidak baku sehingga dalam struktur bahasa membuat kalimat tersebut tidak efektif. Untuk membuat kalimat tersebut efektif maka kata "Nggak" dapat diubah menjadi kata baku yaitu "tidak".

Table 1. Kata Baku Iklan Komersil "Teh Sariwangi"

\begin{tabular}{|c|l|l|}
\hline No. & Kata Tidak Baku & \multicolumn{1}{c|}{ Kata Baku } \\
\hline 1 & Nggak & Tidak \\
\hline
\end{tabular}




\section{JBS'] Jumal Bahase \\ JBS \& ssarta mononsia}

Volume: 1 | Nomor 1 | November 2021 | E-ISSN: 9999-999x | DOI: 10.47709/jbsi.v1i1.1232

\begin{tabular}{|c|l|l|}
\hline 2 & Pake & Pakai \\
\hline 3 & Aja & Saja \\
\hline 4 & Udah & Sudah \\
\hline 5 & Enteng & Ringan \\
\hline 6 & Macem-macem & Macam-macam \\
\hline 7 & Ngumpulin & Mengumpulkan \\
\hline 8 & Gimana & Bagaimana \\
\hline 9 & Kalo & Kalau \\
\hline 10 & Gitu & Begitu \\
\hline 11 & Kembaliin & Kembalikan \\
\hline 12 & Terus & Lalu \\
\hline 13 & Tau & Tahu \\
\hline 14 & Cuma & Hanya \\
\hline
\end{tabular}

Dalam wacana iklan layanan komersil terdapat beberapa kata- kata yang memiliki arti serta makna yang berbeda dengan wujud aslinya yang disampaikan oleh si pembicara tentang iklan layanan komersil tersebut.

Kutipan dialog di atas terdapat pembicaraan antara seorang penjual dan pembeli:

Dialog I

Pembicara : penjual

Pendengar : pembeli

Tempat : warung

Situasi : jual beli

Ketika si pembeli melakukan pembayaran, lalu penjual mengatakan:

“Ah, lima ratus aja, Bu...”.

Dialog II

Pembicara : penjual

Pendengar : pembeli

Tempat : warung

Situasi : jual beli

Ketika si pembeli melakukan pembayaran, lalu penjual mengatakan:

“Ah, lima ratus aja, Bu...".

Kalimat "Ah, lima ratus aja, Bu..." yang diucapkan si penjual pada dialog I dan II memilki bentuk yang sama, tetapi maknanya berbeda. Kalimat pada dialog I, si penjual mengatakan bahwa uang lima ratus rupiah itu tidak nilai/harga kepada si pembeli. Berbeda dengan dialog II kalimat itu memilki makna tidak menghargai pada pembeli karena menganggap kecil uang lima ratus rupiah padahal nilai tersebut dapat membeli permen. Kata ", lima ratus aja pada kalimat dialog II bukan makna yang sebenarnya yang menyatakan pada si pembeli, lima ratus aja, bahkan sebaliknya yaitu tidak menghargai uang sebesar lima ratus rupiah.

Berdasarkan penjelasan di atas, dapat disimpulkan bahwa konteks adalah ruang dan waktu yang meliputi lingkungan fisik dan sosial tertentu dalam memahami suatu teks. Teks yang dimaksud dalam hal ini tidak hanya teks-teks yang dilisankan dan yang ditulis.melainkan termasuk pula kejadian- kejadian yang nirkata 


\section{JBS' Jumal Bahase \\ JBS assatratronosia}

Volume: 1 | Nomor 1 | November 2021 | E-ISSN: 9999-999x | DOI: 10.47709/jbsi.v1i1.1232

(nonverbal) lainnya atau keseluruhan lingkungan teks itu. Selain itu, konteks juga dianggap sebagai penyebab terjadinya suatu pembicaraan atau interaksi komunikasi.

\section{Kesimpulan}

Berdasarkan pembahasan pada penelitian ini penulis dapat menarik beberapa kesimpulan diantaranya:

1. Pemakaian dalam percakapan iklan juga harus memperhatikan kaidah- kaidah Ejaan bahasa Indonesia yang baik dan benar. agar kiranya masyarakat yang mendengarkan iklan komersil dapat mengerti isi dari penyampaian pada iklan tersebut. Hal ini sangat penting mengingat perkembangan zaman yang semakin meningkat dalam hal pertumbuhan bahasa- bahasa asing yang sering digunakan di media massa cetak maupun elektronik.

2. Pemakaian bahasa dalam percakapan iklan komersil yang tidak memperhatikan pemakaian bahasa Indonesia yang baik dan benar akan dapat membuat masyarakat yang mendengarkan tidak dengan mudah mengerti maksud dan tujuannya.

3. Penggunaan Bahasa Indonesia pada percakapan iklan di radio masih terdapat kesalahan dalam pemakaiannya.

Untuk itu penulis sangat berharap besar kepada para pemakai bahasa Indonesia agar kiranya dapat menggunakan bahasa Indonesia sesuai dengan kaidah- kaidah bahasa yang sudah ditetapkan dalam Ejaan Bahasa Indonesia.

Jika pemakai bahasa sudah mampu dalam menerapakan pemakaian bahasa Indonesia yang baik dan benar, maka tugas kita tinggal mengembambangkan pemakain bahasa Indonesia itu ke berbagai daerah dengan selalu berpedoman terhadap Ejaan Bahasa Indonesia yang baik dan benar.

\section{Referensi}

Abdul Rani, Bustanul Arifin, Martutik. 2006. Analisis Wacana Sebuah Kajian Bahasa dalam Pemakaian. Malang: Bayumedia Publishing.

Chaer, Abdul. 2009. Pengantar Semantik Bahasa Indonesia. Jakarta: Rineka Cipta

Edward. 2011. "Definisi Periklanan Menurut Beberapa Ahli" (Online). http://oaththinking.blogspot.com/2011/04.html. (diakses November 2021).

Efendi, Anwar. 2008. Bahasa dan Pembentukan Citra dalam Komunikasi Periklanan di Televisi. Jurnal. Volume 2, No. 2

Indrawati, Sri. 2008. Penggunaan Bahasa Indonesia Pada Informasi Layanan Umum dan Layanan Niaga, Sudah Benarkah? Jakarta

Kusumawati. Analisis Pengguanaan pemakaian Gaya Bahasa Pada Iklan Produk kecanikan Perawatan Kulit Wajah di televisi. 2010. Surakarta. UNS (Tidak Diterbitkan)

Lubis, Dini Aida. 2014. Analisis Relasi Makna Bahasa Iklan Dalam Media Massa. (Tesis). Medan. UMN (Tidak Diterbitkan)

Hakim, Lukman. 2011. Pengertian dan fungsi bahasa (Online). http://lukmannhakimm.blogspot.co.id/2011/11/-pengertian-fungsi.html. (Diakses November 2021).

Mustofa, Amir. 2010. Analisis Wacana Percakapan "Debat TV One”. (Skripsi). Surakarta. UNS (Tidak Diterbitkan) 


\section{JBS|'ungar athas}

Volume: 1 | Nomor 1 | November 2021 | E-ISSN: 9999-999x | DOI: 10.47709/jbsi.v1i1.1232

Mulyana. 2005. Kajian Wacana Teori, Metode, dan Aplikasi Prinsip-Prinsip Analisis Wacana. Yogyakarta: Tiara Wacana

Panggabean, Jason Walker. 2013. Makalah Pragmatik-Sruktur Percakapan (online) tersedia: http://jasonwalkerpanggabean.blogspot.co.id/2013/12/makalah-pragmatik-strukturpercakapan.html. (Diakses November 2021)

Pratiwi, Mega. 2011. Teori Penulisan Bahasa Iklan (Online). http://megapratiwitugas.blogspot.co.id/2011/05/teori-penulisan-bahasa-iklan.html. (Diakses November 2021).

Sumarlam. 2009. Teori dan Praktik Analisis Wacana. Surakarta: Pustaka Karya.

Tim Penyusun Kamus Besar Bahasa Indonesia. Kamus Besar Bahasa Indonesia, (Jakarta: Balai Pustaka, 2003), Cet. III, hlm. 17.

Umry, Shafwan Hadi. 2011. Bahasa Pers, Iklan, dan Bahasawan. Medan: USU Press

Umry, Shafwan Hadi. 2016. Sikap Kita Berbahasa. Medan: CV. Mitra Medan

Yolandi, Sepris. 2012. Pengaruh Iklan, Citra Merek, Dan Kepuasan Konsumen Terhadap loyalitas konsumen dalam menggunakan Vaseline hand and body lotion di kota padang. Jurnal. Volume 3, nomor 2. 